\title{
THE STONE NOVEL OF ÉIRE
}

\author{
NATALIA ABELIAN
}

\section{Introduction: Myths, stones and stars ${ }^{1}$}

Stones and stars are the closest to eternity and the most silent keepers of myths. Myth is a vaccination of eternity to a human being in our changing world.

Myths contain language of a given cultural tradition, together with some scraps of the descriptions of ritual. The stars (or, to be precise, the distinct heavenly bodies, e.g. the sun, the moon, the constellation of Orion, the Pole star etc.) are the elements that have direct connection with the calendar of preliterate traditions and with the prehistoric concept of time which, following K. Jaspers (1949: 53), can be taken as cyclical. Being an intrinsic part of this prehistoric concept of time, the heavenly bodies have a connection with life and death, fertility and harvest. They often figure in myths and turn orientation of the stones to themselves. Furthermore, the stones can keep the traces of the artistic, literary and practical-sacred (ritual-arranging) activity of the perhaps hundreds of generations that inhabited the territories where the stones can be found. In the words of Y. M. Lotman (2000: 367),

A society, which is built upon custom and collective experience, must inevitably have a mighty structure of prognosis. This necessarily stimulates observation of nature, especially of the heavenly bodies, and the associated theoretical cognition. Various forms of descriptive geometry (an ornament, a cross, a circle, a star) can be fully combined with the non-written character of culture as such, having as an addition oral poetry of a calendrical-astronomical nature (my trans.).

In what follows, we shall attempt to define the place of the megalithic stone structures in the outlook of the early Irish culture. We shall include some archaic Irish linguistic elements and look at relevant myths that have survived in various early Irish sources, and, in particular, in the compilation known as The Metrical Dindshenchas (hereinafter $M D$ ). In our contribution, we shall confine ourselves to defining such notions as 'water', 'fertility', 'the Otherworld' that are commonly

\footnotetext{
${ }^{1}$ I would like to acknowledge kind invitation received from Professor Piotr Stalmaszczyk to make a presentation of works of art at the conference and generous advice received from Dr John Carey while preparing this contribution. All misunderstandings and omissions are, however, my sole responsibility.
} 
associated with the megalithic stone structures in early Irish mythology and in Irish folklore beliefs and customs.

\section{Water}

All the stone structures that have any sort of connection with the stars - the dolmens and the Bruig na Bóinde complex which includes New Grange (Síd in Brogo), Knowth (Cnogba) and Dowth (Dubad) have immediate proximity to water, whether above or below the ground; and water is also a feature in the myths associated with some of them. The three mounds of New Grange, Knowth and Dowth are situated in the valley of the rivers Boyne and Mattock and by virtue of their location are surrounded with water (fig. 1).

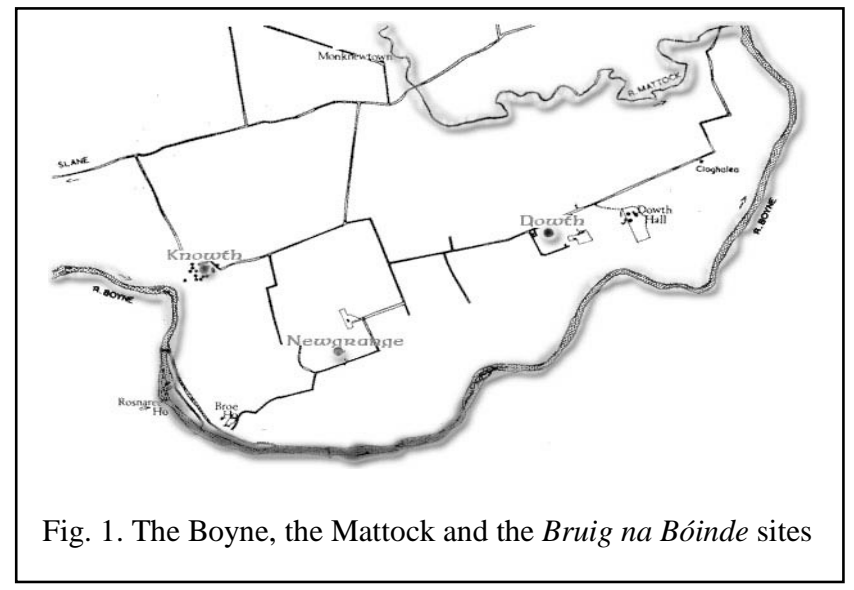

Inside every one of the three mounds, archaeologists have found stone basins that could have contained water (Mac Uistin 2007: 46; see also Borlase 1897: 351, referring to the first published notice of December 1699 visit to New Grange).

However, it is only in the myth about New Grange that the link with water is explicitly contained. The myth connected with the origin of the mound and the river informs us of a sacred well that was inside a síd-mound. Alternatively, there is a legend about the confluence of two springs of important status:

Nó Bóand bó ocus find

Do chomrac in dá ríg-lind

In t-usce a sléib Guaire glé

Ocus sruth na síde-se. S.

Or, Boand is Bo and Find

from the meeting of the two royal streams, the water from bright Sliab Guaire and the river of the Sids here.

(MD III: 32-33, Boand I, lines 77-80). 
Due to Boand's illicit behaviour, the sacred spring bursts out to become a sacred river that bears her name. Another version of the origin-legend of the river Boyne speaks of "a secret well” that was situated inside the síd-mound:

Topur diamair bói 'na dún

assa maided cech mí-rún.

Ní fhail nodécced dia lár

nach maided a dá rosc rán.

A secret well there was in his stead,

from which gushed forth every kind of mysterious evil.

There was none that would look to its bottom:

but his two bright eyes would burst (MD III: 28-29, Boand I, lines 43-46).

The river originating from the spring encircles the whole world, changing its name fifteen times in different locations; having reached Paradise, it returns to the síd. ${ }^{2}$ It is most likely that the message of the composition relates to the unification of multiple fresh waters into a uniform water goddess and the identification of the river Boand with "some kind of universal river" (Carey, p.c.).

The concept of water is also very strongly connected with the dolmens. It has been suggested that the dolmens can provoke 'a dowsing effect' - a geological phenomenon of the underground waters attracted to the heavy boulders (Feeley 2000: 9). If one can presume that prehistoric peoples were aware of such effect, in this case the dolmens presented the structures that caused manifestation of water. They could also have been constructed deliberately near the underwater courses flowing beneath.

The sitting of portal-tombs has a tendency to cling to river valleys, often at an altitude of between $100 \mathrm{~m}$, and almost half of the examples known are located within about 5 miles of the coast (Harbinson 1994: 54).

Scholars who have studied dolmens situated in the Western Caucasian area reached similar results:

Our research indicated that dolmens are situated near water springs. In the vicinity, at a distance of between five and fifty meters there is also a river, a stream, a spring. Even if the dolmen is situated on the slope or the top of a mountain, there is always a spring near it, which can sometimes be an underground one. The water is symbolized by a zigzag ornament found on various dolmens (Kudin n.d., my trans.).

\footnotetext{
${ }^{2}$ See more discussion of the episode in Mac Mathúna (2010) who postulates its connection with the notions of sacred milk and water mythology of the early Irish.
} 


\section{Fertility}

In practical Irish folk medicine the dolmens were used as a cure for childlessness: the person either had to spend a night or to initiate a conception beneath the dolmen.

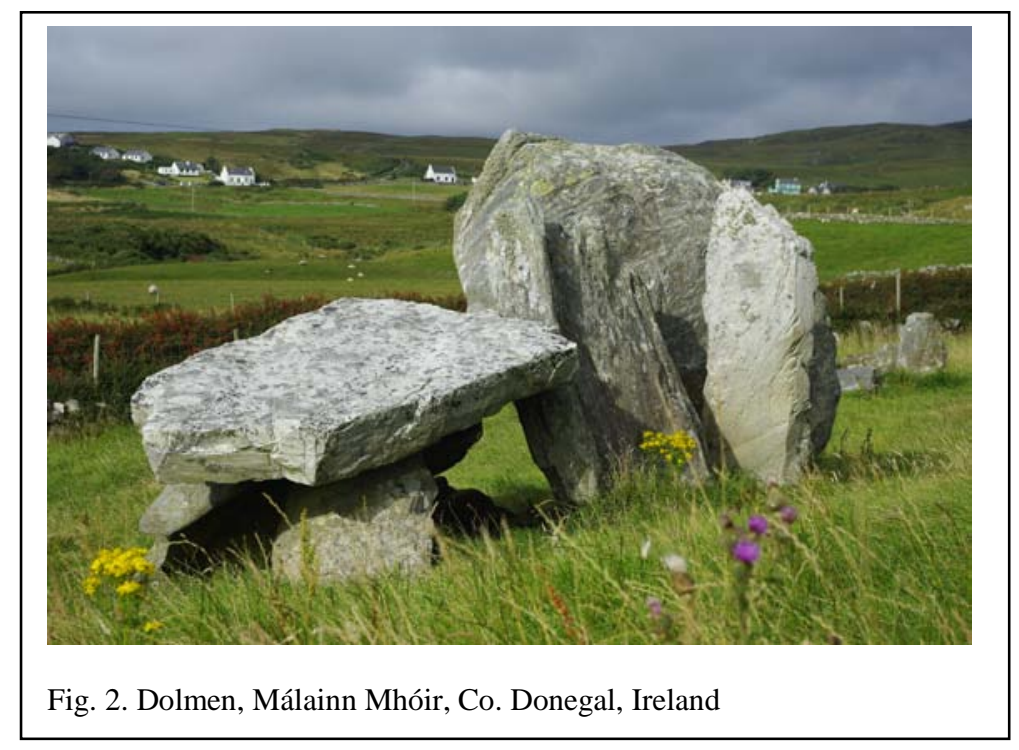

In the western half of Ireland especially, dolmens were once highly valued among women wishing to have a child. In order to facilitate conception, they would have slept on the capstones of the monuments (Zucchelli 2007:128).

In the legends of the Ossianic cycle and in the Modern Irish language and folklore, the dolmens are identified as "the beds of Diarmuid and Gráinne" - the overnight retreat for a pair of lovers who were trying to escape the wrath of Finn, the leader of the fíanna and the prospective groom of Gráinne (Ó hÓgáin 1990: 161-3).

A similar attitude to dolmens as the points of fertility and conception is attested among the people of Adygeya of the North Caucasus, Russia (see fig. 3, note the zigzag ornament on the both sides of the monument symbolising water).

Scholars who have studied these monuments consider that the dolmens in the traditions in question can be interpreted within the framework of the ancient ritual cluster "cave-womb-fertility". 


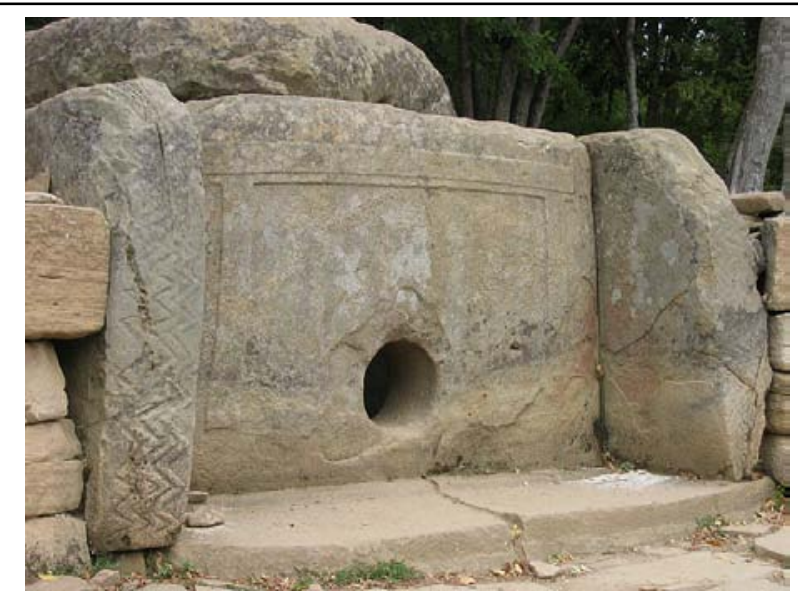

Fig. 3. Central dolmen of the river Zhane complex, Gelendjik, Russia

The dolmen symbolised the World Mountain that encapsulated in her womb a dead person so that the deceased is born again. The fertile substance of the mountain is well-known. She is addressed with the requests for future progeny, and ritual actions to treat barrenness are carried out inside it. Women try to crawl through the hole in the stone, rub themselves at menhirs, drink water from the holes near the dolmens.

The dolmen reproduces the womb of the sacred Mountain - the archaic female first ancestor who is a great parent of all beings, on whom all the life and death of every living being depend. The embodiment and formation of this common idea was different in various parts of the megalithic universe, but everywhere the cult of the World Mountain was connected with the cult of fertility and of reproduction (Kyzlasov 1993: 112, my trans.).

In general, dolmens are wide-spread in Western Europe (Ireland, Great Britain, Bulgaria, France, the Netherlands, Belgium, Spain, Italy), in Armenia, in Russia (along the Black Sea coast and in the mountains of the Western Caucasus, of the Altai region and in the vicinity of Ryazan as well as in the south of the Chelyabinsk region). They can also be found in Northern Africa (e.g. at Rocknia, a prehistoric necropolis situated in the region of Gelm in the North-East of Algeria) and in Asia (e.g. South Korea, Mongolia). 


\section{Analysis of the Boyne valley complex mythological motifs}

In this part of our contribution, we shall compare the legends on the origin of the three mounds in question. We shall set the symbols and topics contained in the stories about each of them side by side with each other, pointing out the motif of fertility as the central one:

New Boand, Nechtain's wife, walks around his sacred well (located inside New Grange Grange) after having had an adulterous inter-course with Dagda and given birth to their son, Oengus. The well over-flows, and drowns Boand:

Tánic Bóand ann andes ben Nechtain cosin cairdes co tech Elcmairi na n-ech fer dobered mór ndeg-breth.

Is ann dorala in Dagda i tig Elcmairi amra: rogab for guide na mná rodusasáit re hóen-lá...

Luid Bóand ó thig co tric dús dá tairsed in tiprait: derb lé docheiled a col da soised lé a fothrucod...

Doruacht Bóand mín dochum na tiprat iar fír: ércid tairsi in tobar tenn, corosbáid hí cen forchenn
Thither from the South came Boand wife of Nechtain to the love-tryst to the house of Elcmaire, lord of horses a man that gave many a good judgement.

Thither came by chance the Dagda into the house of famous Elcmaire he fell to importuning the woman: he brought her to the birth in a single day.

Boand went from the house in haste to see if she could reach the well: she was sure of hiding her guilt if she could attain to bathe in it...

Came gentle Boand toward the well in sooth: the strong fountain rose over her and drowned her finally.

(MD III: 37, Boand II, lines 25-32, 41-4, 52-3)

Knowth Mider has an intercourse and escapes with his lover, Englec, who is the beloved of Oengus and the daughter of Elcmar. Oengus goes in search of the girl, casting nuts on the ground, hence chnó-guba 'nut-wailing' is K.'s name:

Ingen Elcmair ann robái Ba lendán Mider don mnái...

Englec ingen Elcmair áin Lendán Óengussa imláin Óengus mac in Dagdai dil Nírbo lendán don ingin.

Dolluid mac in Óc ergna fodess co Cerainn Cermna 'sin tshamuin teintig thríallaig do chluiche fri comfhíannaib.

Dolluid Mider, messu de, rosfarraid daranése
Elcmar's daughter lived there:

Mider was the woman's darling...

Englec, noble Elcmar's daughter, was the darling of perfect Oengus; Oengus, son of the loved Dagda, was not the maiden's darling.

The illustrious Mac in Oc (i.e. Oengus) came southward to Ceru Cermna on the blazing hurrying Samhain to play with his fellow-warriors

Midir came - alas the day!

he came upon her after they had gone 
berid Engleic leis ó thig

assin co Síd Fer Femin.

Ó rochúala Óengus án

a lenmain imma lendán, dothéit dia fochmairc, fír dam, cosin rochnocc óa rucad.

Rob é lón a shlúaig, líth nglé, cnói cró-derga na caille; léicid a lón de for lár, feraid guba immon cnocán. he carries off with him Englec from her home thence to the síd of the men of Femen.

When noble Oengus heard of the pursuit of his darling, he went in search of her to the famous hill whence she was borne off.

This was the food of his band - bright feast blood-red nuts of the wood; he casts the food from him on the ground; he makes lamentation around the hillock.

(MD III: 40-43, Cnogba, lines 13, 17-18, 21-36, 39-40)

Dowth Murrain comes upon Bresal's kingdom, hence all the cattle is destroyed, save for seven cows and a bull. In order to restore the kingdom's prosperity, he orders a tower similar to the Nimrod's Tower to be built in one day and one night. To complete the task, his sister helps him using her magic to stop the heavenly bodies from their course. The girl is violated by Bresal, her magic is destroyed and the task is not completed:

Luidh Bresal na díaidh 7 com- Bresal followed her and had union with raicidh fría, conidh ón chul her: so that place is called Ferta Cuile from doronadh and raiter Ferta the incest that was committed there. Night Chuile don inadh. Taínic came upon them, for the maiden's magic adhaidh doibh iarsin, ar was spoilt. romilledh a draighecht mon $n-$ inghin.

(MD IV: 272-3, Dubad)

All in all, these legends tell us about women located in/near the Otherworld (the síd). Clearly, there is a good deal of further overlap in symbolism among the three legends. All of the three speak about some form of sinful sexual behaviour. In the first legend, the myth not only speaks of the drowning of Boand, but alludes to the conception and birth of the most beautiful child, Oengus; and the treatment of Boand, though destructive, can yet be taken to be purificative and cleansing. Here, the topic of a sinful conception and subsequent retribution for the sin is probably a result of a Christian re-interpretation of the theme. Symbolically, we have an indirect reference to the theme of fertility, of a womb as its source and of its purification with water. In the second story, nuts that Oengus casts on the ground can be interpreted as symbols of his love (cf. co cnóib serce Segsa, 'with love-nuts of Segais', MD III: 131.31, Rath Cnamrossa) or else nuts of 'doubt and uneasiness' (cnói amruis anshádail, ib., line 36); presumably, of Oengus who is upset by his lover's adulterous encounter with Mider. In the final legend, Bresal commits incest with his sister and destroys her magic and fails to fulfil his royal task that his people were trying to accomplish. 


\section{The Otherworld}

As we have just pointed out, the three legends in question (directly or indirectly) refer to the underground Otherworld. Moreover, the first and the last legends provide references to the link existing between a female character of a legend and the upper world. In the legend on the origin of Dowth, the king's sister, having raised her hands to the heavens, stood on a hill and made a druidic spell to control the course of the sun, preventing it from setting:

Sínid uaithe a fiur for fecht, doní co dron a drúidecht: nir utmall grían ósa cind; rofasta hí 'sin oen-rind...

His sister stretches forth her hands... strongly she makes her druid spell: the sun was motionless above her head; she checked him on one spot.

(MD III: 44-5, Cnogba)

In the legend, the aspiration of the king to reach the heavens (comadh de nodigsitis dochum nime, 'that they might go by it to heaven', MD IV: 272-3, Dubad) can be interpreted as an allegory that signifies the aspiration to "find out the mysteries of the sky", i.e. to carry out astronomical observations.

In the New Grange legend, as we have already mentioned, Boand is transformed into a world river flowing everywhere, including the Heavens.

It is well-known that as far as New Grange is concerned, the central line of the passage leading to its burial chamber is purposefully aligned at the point of the winter solstice (21 December). In the morning of the day, as well as during the fifteen-day period before and after the solstice, "a pencil-thin ray of sunlight penetrates the chamber for a mere seventeen minutes, from 8.58 to 9.15 am winter time” (Harbinson 1994: 76). In so far as the three mounds of New Grange, Knowth and Dowth were seen as a single sacred complex, it may well be proposed that the Bruig na Bóinde complex on the whole was most likely connected with the idea of time observation. Central to this activity was probably the annual observation of the point on the horizon where the sun rises on the shortest day of the year, symbolising the start of a new cosmic cycle. Such deliberate orientation to a point of the rebirth of a cosmic temporal cycle (which probably figured in the outlook of the prehistoric settlers that inhabited Ireland) and their specific location at the energetic fertility nexus - in connection with the underground water courses - may have provoked the creation of myths and legends concerned with fertility. In this regard, the megalithic structures were linked both with the underground and the upper world, i.e. the underground and celestial realms were probably viewed as aspects of a single Otherworld in the pre-literate culture of early Ireland. 


\section{Conclusion}

Our conclusions are indirectly supported by the early Irish linguistic evidence. V. Kalygin (2002: 92) in his work on Celtic cosmology refers to the textual data relating to the correlation of darkness, water and the origin of the universe in the early Irish language:

EIr. domun 'world' is a regular continuation of the stem *domn- $<*$ domno-s $<$ *dubno- (MW. dwfn, Bret. doun 'deep') and is related to Ir. domain 'deep; riverbed, depth' < *dubni- and *dobur- 'dark; water' < *dubro- (MW dwfr 'water', dyffryn 'plain' <*dubro-senton 'water course').

(Kalygin 2002: 92; my trans.)

He also refers to the evidence of Ogam inscriptions, archaic Irish poetry and Welsh sources:

EIr. Domongein < *dubno-geno-s, which is sometimes interpreted as 'Son of the Earth; Born by the Earth' (Korolev 1984: 147);

EIr. Doborgen < *dubro-geno-s 'born by the water'

EIr. Domnal < *dubno-walo-s 'lord of the world';

EIr. Domongart < *dumno-garto-s 'head/beginning of the world' (*gart as in vocalic EIr. gloss gart .i. cend, related to the Welsh garth 'hill, mound')...

In Welsh, among the derivatives from the stem *dubno-/*dubro, are represented, besides the aforementioned $d w f n$ and $d w f r$, such words as anoddyn 'abyss' < *anwo-dubno-, and Annwfn/Annwfyn 'the Otherworld' < ... *ande-dubno that can be interpreted as either 'under-lower/dark' or 'the very lowest/darkest'.

(Kalygin 2002: 92-3, 96; my trans.)

On the basis of the above linguistic data, we can suppose that the ideas of depth, water, darkness and the source of the universe were productive and life-giving principles in early Irish cosmology and consciousness. These attributes are transferred onto the stone which thus becomes a mediator between the underworld and the upper world.

On the one hand, the stone points at the movements of the stars and other celestial objects; on the other, at the movement of the waters - the underground springs. From this we can infer that the humans of the early times aligned their activity not only with the cosmic energies, but also with those of the inner earth. The central element in this triadic system was the stone itself and the world of humans. The celestial character of the latter should not be taken in the Christian sense, but in the one that established the character and the time of rituals due to the cyclicity of the movement of the heavenly bodies, and thereby regulated the annual cycle of human activity. The sky was the law and yet, was a calendar. The underground was the world that granted fertility. The stone structures absorbed the "upper" and the "lower" attributes of both worlds and were seen as providers of fertility in folk belief. 
We have come to the conclusion that the megalithic stones became connected with two positive sources in the pre-literate culture of early Ireland: the dark and wet source of fertility in the Otherworld situated under the ground; and the light and sunny source of the conception of the new life and of the new year in the celestial Otherworld. The stone was the eye and the door of the Otherworld: it was able to generate and return the energies transmitted to it, and was associated with fertility, revival and recovery. ${ }^{3}$

Coleraine, Northern Ireland

\begin{abstract}
Abbreviation
MD - The Metrical Dindshenchas (Gwynn 1903-1935)
\end{abstract}

\title{
References
}

Borlase, W., 1897, The Dolmens of Ireland, Their Distribution, Structural Characteristics, and Affinities in Other Countries; together with the Folklore attaching to them; supplemented by Considerations on the Anthropology, Ethnology, and Traditions of the Irish people. With four maps, and eight hundred illustrations, including two coloured plates, London: Chapman \& Hall.

Carey, J., 1990, 'Time, Memory, and the Boyne Necropolis', Proceedings of the Harvard Celtic Colloquium 10, 24-35.

Feeley, J. M., 2000, 'Carlow Dolmens', lecture to Old Carlow Society, in: Megaliths of Ireland: South East Region, An On-line Dolmen Survey (available at http://glasnost.itcarlow.ie/ feeleyjm/archaeology/index2.htm; accessed 30.08.10).

Gwynn, E., ed., 1905-35, The Metrical Dindshenchas, 5 pts, Dublin: RIA.

Harbison, P., 1994, Pre-Christian Ireland, London: Thames \& Hudson.

Jaspers, K., 1949, Vom Ursprung und Ziel der Geschichte, München: Piper \& Co. [1953, The Origin and Goal of History, London: Routledge \& Kegan Paul].

Kalygin, V., 2002, 'Kel’tskaya kosmologiya' ['Celtic Cosmology'], in: Kalygin, V. P., Mikhailova, T. A., Toporova, T. V., eds., Predstavleniya o smerti $i$

\footnotetext{
${ }^{3}$ As well as with justice and law. The analysis of the complex subject of the character and origin of the standing and inaugurating stones that bear connotations of justice and truth requires additional research. Let us briefly note that, for instance, nineteenth-century Irishmen used perforated stones for sealing contract agreements and marriage engagements: "prior to the intervention of the Church, the Bargaining Stone has been a popular meeting place to settle all kinds of contracts from marriage arrangements to the sale of land. The parties would shake hands through the hole to affirm the deal" (Zucchelli 2007: 124).
} 
lokalizaciya inogo mira u kel'tov i germancev [Ideas of Death and Location of the Otherworld in Early Celtic and Germanic Traditions], Language - Semiotics- Culture: Series Minor, Moscow: Yazyki Slavyanskoi Kul'tury, 82-109.

Korolev, A. A., 1984, Drevneishiye pamyatniki irlandskogo yazyka [The Earliest Monuments of the Irish Language], Moscow: Nauka.

Kudin, M.I., n.d., Dol'meny i ritual [Dolmens and Ritual], http://risk.fatal.ru/pb7.htm, accessed 28.03.2010); first publication 1999, Sochi: Sochinsky krayeved, 4.

Kyzlasov, I. L., 1993, 'Mirovozzrencheskaya osnova pogrebal'nogo obryada' ['Worldview Basis of the Burial Ritual'], Russian Archaeology 1.

Lotman, Y. M., 2000, 'Vnutri myslyaschikh mirov. Al'ternativnyi variant: bespis'mennaya kul'tura ili kul'tura do kul'tury' ['Inside the Thinking Worlds. Part 3. Alternative variant: non-literate culture or culture before culture?'], in: id., Semiosfera [Semiosphere], St. Petersburgh: Iskusstvo$\mathrm{SPb}, 149-390$.

Mac Mathúna, S., 2010, 'Sacred Landscape and Water Mythology in Early Ireland and Ancient India', in: Fomin, M., Mac Mathúna, S. \& Vertogradova, V., eds., Sacred Topology in Early Ireland and Ancient India: Religious Paradigm Shift, Journal of Indo-European Studies Monograph Series 57, Washington: Institute for the Study of Man, 3-53.

Mac Uistin, L., 2007, Exploring Newgrange, Dublin: The O'Brien Press.

Ó Cathasaigh, T., 1989, 'The Eponym of Cnogba', Éigse 23, 27-38.

Ó hÓgáin, D., 1990, Myth, Legend and Romance. An Encyclopaedia of the Irish Folk Tradition, London: Ryan Publishing.

O’Kelly, M., 1988, Newgrange - Archaeology, Art and Legend, London: Thames \& Hudson.

Zucchelli, C., 2007, Stones of Adoration. Sacred Stones and Mystic Megaliths of Ireland, Dublin: The Collins Press. 